\title{
PEWARISAN NILAI TRADISI NGABUNGBANG DALAM PEMBELAJARAN \\ SEJARAH LOKALDENGAN METODE EKSKURSI PADA MAHASISWA PROGRAM STUDI PENDIDIKAN SEJARAH FKIP UNIVERSITAS GALUH
}

Oleh:

Wulan Sondarika, Yeni Wijayanti, dan Agus Budiman

Prodi Pendidikan Sejarah FKIP Universitas Galuh

Email:wulansondarika13@gmail.com,

\begin{abstract}
Abstrak
Tujuan khusus penelitian ini adalah untuk mengetahui nilai-nilai sejarah dalam Tradisi Ngabungbang dan untuk mengetahui sejauh mana pewarisan nilai-nilai sejarah Tradisi Ngabungbang diterapkan dalam pembelajaran sejarah yang menggunakan metode ekskursi.Penelitian ini dilakukan di Program Studi Pendidikan Sejarah FKIP Universitas Galuh Ciamis, studi kasus pada mahasiswa tingkat 1, dengan menggunakan metode penelitian deskriptif kualitatif. Pengumpulan data dilakukan dengan observasi, wawancara, dan analisis dokumen. Hasil penelitian menunjukkan bahwa Tradisi Ngabungbang dilaksanakan setiap tanggal 14 bulan Maulud di Desa Batulawang Kecamatan Pataruman Kota Banjar. Nilai-nilai Tradisi Ngabungbang yang diantaranya ada nilai religius, estetis, ekonomis, sosial, kedisiplinan, demokratis, kreatif, kejujuran, cinta tanah air dan lainnya. Sebagian besar mahasiswa dapat memahami nilai-nilai yang terkandung dalam Tradisi Ngabungbang.
\end{abstract}

\section{Kata Kunci: Nilai Sejarah, Tradisi Ngabungbang, Sejarah Lokal, Ekskursi}

\begin{abstract}
The specific purpose of this research is to know the historical values in Ngabungbang Tradition and to know the extent of the inheritance of historical values Ngabungbang tradition applied in learning history using excursion method.This research was conducted in History Studies Program History FKIP Galuh Ciamis University, case study in the first grade students, using qualitative descriptive research method. Data collection is done by observation, interview, and document analysis. The results showed that Ngabungbang Tradition was held every 14 months Maulud in Batulawang Village, Pataruman Sub District, Banjar City. The values of the Ngabungbang Tradition are religious, aesthetic, economical, social, disciplinary, democratic, creative, honesty, homeland and other values. Most students can understand the values contained in the Ngabungbang Tradition.
\end{abstract}

Keywords: Historical Value, Ngabungbang Tradition, Local History, Excursion 


\section{Pendahuluan}

Sejarah merupakan peristiwa masa lampau umat manusia. Semua peristiwa adalah sejarah, tetapi hanya peristiwa-peristiwa penting yang dapat katakan sejarah. Peristiwa tersebut dapat terjadi pada semua umat manusia dan pada sekelompok masyarakat.Sebuah masyarakat dapat dikenali melalui kebudayaan. Tidak mungkin ada kebudayaan tanpa masyarakat, dan setiap masyarakat melahirkan kebudayaan sendiri. Maka kelangsungan eksistensi sebuah masyarakat sangat terkait dengan upaya masyarakat dalam mempertahankan tradisi.

Upacara tradisional merupakan salah satu wujud peninggalan kebudayaan. Kebudayaan adalah warisan sosial yang hanya dimiliki oleh warga masyarakat pendukungnya dengan jalan mempelajarinya. Ada cara-cara atau mekanisme tertentu dalam tiap masyarakat untuk memaksa tiap warganya mempelajari kebudayaan yang di dalamnya terkandung norma-norma serta nilainilai kehidupan yang berlaku dalam tata pergaulan masyarakat yang bersangkutan. Mematuhi norma serta menjunjung nilai-nilai itu penting bagi warga masyarakat demi kelestarian hidup bermasayarakat (Purwadi, 2005:1).

Budaya juga merupakan identitas bangsa yang harus dihormati dan dijaga serta perlu dilestarikan agar kebudayaan kita tidak hilang dan bisa menjadi warisan anak cucu kita kelak. Hal ini tentu menjadi tanggung jawab para generasi muda dan juga perlu dukungan dari berbagai pihak, karena ketahanan budaya merupakan salah satu identitas suatu negara. Kebanggaan bangsa Indonesia akan budaya yang beraneka ragam sekaligus mengundang tantangan bagi seluruh rakyat untuk mempertahankan budaya lokal agar tidak hilang ataupun dicuri oleh bangsa lain. Sudah banyak kasus bahwa budaya kita banyak yang dicuri karena ketidakpedulian para generasi penerus, dan ini merupakan pelajaran berharga karena Kebudayaan Bangsa Indonesia adalah harta yang mempunyai nilai yang cukup tinggi di mata masyarakat dunia.

Namun, pada akhir-akhir ini perkembangan ilmu pengetahuan dan teknologi sangat begitu pesat dan tidak dapat dipungkiri lagi akan berdampak pada lahirnya arus globalisasi dan modernisme yang mengakibatkan terjadinya pergeseran dalam struktur masyarakat. Derasnya arus globalisasi telah membawa pengaruh terhadap terkikisnya rasa kecintaan budaya lokal dan rasa kebanggaan sebagai bangsa Indonesia.

Oleh karena itu, untuk menghadang pengaruh globalisasi, lembaga pendidikan sebagai salah satu wadah untuk mentransfer perkembangan ilmu pengetahuan mempunyai peranan yang sangat penting dalam menanamkan nilai-nilai yang ada di masyarakat, itu dapat dipelajari melalaui pembelajaran sejarah.Dalam hal ini peneliti menggunakan contoh yaitu tradisi Ngabungbang di Kota Banjar karena tradisi ini merupakan tradisi asli orang Sunda yang hampir punah dan sudah banyak ditinggalkan oleh masyarakat tatar Sunda.

Dalam proses pembelajaran sejarah diperlukan suatu model pembelajaran yang bervariasi dengan menggunakan pembelajaran kontekstual, yang ada di sekitar mahasiswa. Salah satu model yang dapat diterapkan dan berkaitan dengan upaya pemanfaatan peninggalan 
sejarah adalah model pembelajaran kontekstual atau CTL (Contextual Teaching and Learning). Pembelajaran CTL merupakan konsep pembelajaran yang menekankan pada keterkaitan antara materi pembelajaran dengan dunia kehidupan nyata, sehingga mahasiswa mampu menghubungkan dan menerapkan kompetensi hasil belajar dalam kehidupan sehari-hari. Dalam pembelajaran kontekstual, tugas guru adalah memberikan kemudahan belajar kepada mahasiswa, dengan menyediakan berbagai sarana dan sumber belajar yang memadai. Guru bukan hanya menyampaikan materi pembelajaran yang berupa hafalan, tetapi mengatur lingkungan dan strategi pembelajaran yang memungkinkan mahasiswa belajar. Kegiatan mahasiswa dalam pembelajaran kontekstual diarahkan agar mahasiswa melakukan sharing untuk memperoleh masukan dan tanggapan dari orang lain. Situasi belajar dibuat menyenangkan dan tidak membosankan sehingga mahasiswa belajar dengan gairah dan minat yang tinggi. Salah satu metode yang dapat digunakan untuk pembelajaran kontekstual ini adalah metode ekskursi. Pembelajaran dengan menggunakan metode ekskursi dilakukan agar mahasiswa lebih termotivasi pada mata kuliah sejarah lokal, lebih aktif dalam menggali dan menganalisis peristiwa sejarah, memahami fakta-fakta sejarah yang dekat dengan lingkungan tempat tinggal mahasiswa, dan suasana kegiatan belajar mengajar tentunya akan lebih menyenangkan.

Berdasarkan uraian di atas, maka peneliti merasa tertarik untuk mengkaji dan mengangkat permasalahan tersebut dalam judul penelitian "Pewarisan Nilai Tradisi
Ngabungbang Dalam Pembelajaran Sejarah Lokal Dengan Metode Ekskursi Pada Mahasiswa Program Studi Pendidikan Sejarah FKIP Universitas Galuh".

Berdasarkan latar belakang yang telah diuraikan di atas dan agar hasil penelitian ini lebih terfokus, maka dapat dirumuskan permasalahan penelitiannya adalah sebagai berikut.

1. Bagaimana pelaksanaan Tradisi Ngabungbang?

2. Bagaimana pewarisan nilainilai sejarah Tradisi Ngabungbang dalam pembelajaran Sejarah Lokal dengan metode ekskursi pada mahasiswa Program Studi Pendidikan Sejarah?

\section{Kajian Literatur}

\section{Nilai}

Nilai merupakan standarstandar perbuatan dan sikap yang menentukan siapa kita, bagaimana kita hidup, dan bagaimana kita memperlakukan orang lain.Sedangkan menurut Kalvin dalam Sutarjo Adi Susilo (2013: 56) nilai merupakan preferensi yang tercermin dari perilaku seseorang, sehingga seseorang akan melakukan atau tidak melakukan seseuatu bergantung pada sisi nilai yang dipegangnya. Nilai akan selalu berhubungan dengan kebaikan, kebijakan dan keluhuran budi serta akan menjadi sesuatu yang dihargai dan di junjung tinggi serta dikejar oleh seseorang sehingga ia merasakan adanya sesuatu kepuasan, dan ia menjadi manusia yang sebenarnya.

2. Pembelajaran Sejarah

$$
\text { Pembelajaran sejarah }
$$
beresensikan pada pendidikan nilai, sehingga pendidikan sejarah harus memberikan perhatiannya kepada pengembangan nilai, dan sikap 
perilaku siswa.Para pakar telah mengemukakan berbagai teori tentang pendidikan nilai moral. Menurut Hersh dalam Kokom Komalasari(2010: 88) mengemukakan bahwa diantara berbagai teori yang berkembang, ada enam teori yang banyak digunakan, yaitu; pendekatan pengembangan rasional, pendekatan pertimbangan, pendekatan klarifikasi nilai, pendekatan pengembangan moral kognitif, dan pendekatan perilaku sosial. Berbeda dengan klasifikasi tersebut, Elias

mengklasifikasikan berbagai teori yang berkembang menjadi tiga, yakni; pendekatan kognitif, pendekatan afektif, dan pendekatan perilaku. Klasifikasi ini menurut Rest (1992) didasarkan pada tiga unsur moralitas, yang biasa menjadi tumpuan kajian psikologi, yakni; perilaku, kognisi dan afeksi.

3.Metode Ekskursi

Ekskursi berasal dari kata "excursion" yang artinya darmawisata, pesiar. Metode ekskursi atau metode karyawisata memiliki arti sendiri yang berbeda dengan karyawisata dalam pengertian umum. Karyawisata sebagai sebuah metode berarti kunjungan ke luar kelas dalam rangka belajar. Sebagai suatu variasi dalam proses belajar, kadang-kadang siswa/mahasiswa perlu diajak ke luar sekolah untuk meninjau/mengunjungi tempat tertentu atau objek lain. Hal ini bukan sekedar rekreasi, tetapi untuk belajar atau memperdalam pelajarannya dengan melihat kenyataan di lapangan. Sehingga dapat dikatakan bahwa metode karyawisata adalah cara mengajar yang dilaksanakan dengan mengajak siswa/mahasiswa kesuatu tempat atau objek tertentu di luar sekolah/kampus untuk mempelajari sesuatu (Suryani dan Leo Agung, 2012:65).

Menurut Roestiyah, metode Fieldtrip ialah cara mengajar yang dilaksanakan dengan mengajak siswa/mahasiswa kesuatu tempat atau obyek tertentu di luar sekolah untuk mempelajari atau menyelidiki sesuatu seperti meninjau pabrik sepatu, suatu bengkel mobil, took serba ada, peternakan, perkebunan, lapangan bermain dan sebagainya (Roestiyah, 2001:85). Sedangkan menurut Syaiful Sagala (2006:214) metode fieldtrip ialah pesiar (ekskursi) yang dilakukan oleh para peserta didik untuk melengkapi pengalaman belajar tertentu dan merupakan bagian integral dari kurikulum sekolah/kampus.

\section{Metode Penelitian}

Berdasarkan

konteks

permasalahan dalam penelitian ini maka bentuk penelitian yang dipilih adalah penelitian kualitatif deskriptif.Penelitian deskriptif dirancang untuk memperoleh informasi tentang status gejala saat penelitian dilakukan.Tujuan penelitian ini adalah untuk melukiskan variabel atau kondisi "apa yang ada" dalam suatu situasi (Furchan, 2011: 447).Berdasar dari tujuan penelitian, jenis penelitian ini adalah penelitian dasar (basic research). Menurut Gay dalam Sugiyono, penelitian dasar bertujuan untuk mengembangkan teori dan tidak memperhatikan kegunaan langsung yang bersifat praktis (Sugiyono, 2013:4).

Penelitian kualitatif adalah prosedur penelitian yang menghasilkan data deskriptif berupa kata-kata tertulis atau lisan dari orang-orang dan perilaku yang diamati. Penelitian kualitatif adalah penelitian yang bermaksud untuk memahami 
fenomena tentang apa yang dialami oleh subjek penelitian, misalnya perilaku, persepsi, motivasi, tindakan, dan lain-lain secara holistik dan dengan cara deskriptif dalam bentuk kata-kata dan bahasa, pada suatu konteks khusus yang dialami dengan memanfaatkan berbagai metode alamiah (Moleong, 2006: 6).

\section{Hasil Penelitian dan Pembahasan}

\section{Pelaksanaan Tradisi Ngabungbang}

Kota Banjar merupakan salah satu kota di Jawa Barat yang juga banyak memiliki potensi budaya dan kesenian. Kota Banjar merupakan kota pemekaran dari Kabupaten Ciamis dengan letak geografis berada pada wilayah ujung Timur Provinsi Jawa Barat. Letak geografis Kota Banjar ini di sebelah selatan berbatasan langsung dengan wilayah Kecamatan Wanareja dan Dayeuhluhur Kabupaten Cilacap Jawa Tengah, dan Lakbok Kabupaten Ciamis. Di wilayah Timur ini sangat tepat karena sebagai wilayah perlintasan jalur utama dibagian selatan. Wilayah kota Banjar sebelah Utara berbatasan dengan Kecamatan Cisaga Kabupaten Ciamis dan wilayah selatan berbatasan dengan Kecamatan Lakbok dan Kecamatan Pamarican Kabupaten Ciamis, serta wilayah barat berbatasan dengan Kecamatan Cimaragas dan Kecamatan Cijeunjing Kabupaten Ciamis. Letak geografis kota Banjar ini, berada pada posisi geografis 07 derajat,19 - 07 derajat 26 Lintang Selatan dan 108 derajat 26 108 derajat 40 Bujur Timur (Undang Sudrajat, 2013: xxii).

Kota Banjar memiliki empat Kecamatan, diantaranya adalah Kecamatan Pataruman, Kecamatan Purwaharja, Kecamatan Lanngensari dan Kecamatan Banjar. Desa
Batulawang terletak di Kecamatan Pataruman. Desa Batulawang berada di wilayah Kecamatan Pataruman berbatasan dengan Desa Sukamukti di sebelah barat, dengan Desa Hegarsari dan gunung Sangkur di sebelah utara, dengan Desa Karyamukti di sebelah timur, dan dengan sungai Ciseel dan sebelah selatan yang memisahkan dengan Desa Kertawaringin.

Masyarakat Desa Batulawang merupakan desa yang masih memegang teguh adat istiadat atau tradisi nenek moyang yang salah satunya adalah tradisi Ngabungbang yang rutin dilaksanakan setiap setahun sekali. Mata pencaharian masyarakat Desa Batulawang pada umumnya adalah petani. Kehidupan sebagai masyarakat agraris telah melatar belakangi keadaan sosial budaya penduduk Desa Batulawang. Kehidupan tolong menolong, gotong royong masih terpelihara dengan baik dan dilaksanakan baik dalam keluarga masing-masing, dalam kehidupan bertetangga maupun dalam kehidupan bermasyarakat secara umum. Hal ini tampak antara lain dalam kegiatan atau upacara atau ritual.

Dari beberapa upacara tradisional masyarakat Desa Batulawang yang sudah dijadikan agenda tahunan Kota Banjar Jawa Barat adalah upacara tradisi Ngabungbang yang dilakukan pada malam hari dan bertepatan pada bulan purnama. Upacara ini dilakukan baik oleh para orang tua maupun oleh anak-anak. Dalam tradisi Ngabungbang ini, lebih identik pendekatan diri manusia terhadap Tuhan yang menciptakan alam semesta dan pendekatan manusia antar sesama. Bahwasanya di dalam kebudayaan mengakui alam dalam arti seluasluasnya sebagai ruang pelengkap untuk semakin memanusiakan dirinya, yang 
identik dengan kebudayaan alam. Manusia tidak menguasai alam, namun mengetahui dan memanfaatkannya (Sastrawidjaja dan Mursidin, 2006: 2).

Prosesi Tradisi Ngabungbang terdiri dari pra pelaksanaan dan pelaksanaan, untuk lebih jelasnya dapat digambarkan sebagai berikut

\section{Pra Pelaksanaan}

Untuk mengawali pelaksanaan ritual Ngabungbang, maka tokoh adat setempat mencari waktu yang tepat untuk melaksanakan ritual tersebut.Adapun persiapan yang dilakukan sebelum pelaksanaan tradisi Ngabungbang diantaranya:

1. Damel obor atau damar sewu. Persiapan awal adalah membuat damar sewu, yaitu obor yang terbuat dari bambu dan sumbuyang dinyalakan dengan bahan bakar minyak tanah. Ada beberapa damar sewu yang harus dibuat, diantaranya adalah damar sewu utama, damar tiga kaki, dan damar biasa.

2.Damel Beleketepe. Beleketepe yaitu tempat duduk atau tikar yang terbuat dari janur yang telah didoakan oleh Ki Demang (Agus Safyudin, tokoh masyarakat Desa Batulawang). Ketentuan daun yang bisa dibuat beleketepe adalah harus janur kelapa pertama dari pohon yang belum pernah dipetik dan belum berbuah. Janur juga bisa dari pohon yang pertama kali berbuah atau kelapa indung.

3.Damel Sajen. Yang terakhir adalah membuat sajen atau sesaji. Tugas ini diemban oleh para ibu. Sesaji yang dibuat ada dua macam, yaitu sesaji rempah-rempah (terdiri dari bawang, cabe merah, bawang putih, kelapa, tantung angin, kopi manis, kopi pahit, teh manis, teh pahit, rujak pisang, rujak kembang, batu, rokok bangjo, rokok daun kawung, rokok daun jagung, terasi, daun sereh, dan congcot) dan sesaji nasi kuning (terdiri dari nasi kuning, kacang, telur rebus, wortel rebus, mentimun, cabe merah, daun surawung, kol, jeruk, pisang, dan salak).

\section{Pelaksanaan Ritual}

Tata cara pelaksanaan tradisi Ngabungbang terbagi menjadi beberapa tahapan:

\section{Seja Unjukan}

Seja unjukan merupakan ritual berdoa kepada penguasa bumi Allah SWT, para leluhur untuk meminta izin supaya dilindungi dari segala halangan seperti gangguan dari hal-hal yang gaib.

Seja unjukan ini dipimpin oleh tokoh agama desa Batulawan

Seja Unjukan ini bertempat pendopo. Ada dua macam doa dalam seja unjukan, diantaranya adalah tawasul dan ijab qabul.

2. Menyalakan damar sewu

Setelah melaksanakan tawasulan atau doa, maka acara selanjutnya adalah menyalakan damar sewu, hal ini menandakan bahwa acara sudah dimulai.

3. Menyambut Menak Nagara atau tamu

Tamu-tamu yang menghadiri tradisi Ngabungbang, merupakan tamu dari pemerintahan kota Banjar seperti Wali Kota dan Wakil Wali Kota beserta yang lainnya.

4. Ritual Seremonial 
a. Acara pertama yaitu pembukaan

b. Sambutan dari Kepala Desa Batulawang dan Wali Kota Banjar

c. Pentas kesenian Gondang Buhun dan pencak silat

d. Pentas kaulinan barudak (permainan anak-anak)

e. Pembacaan sejarah Desa Batulawang

f. Pembacaan sabda kanjeng dalem pergaulan, petuah untuk masyarakat Desa Batulawang.

g. Pembacaan puisi yang berjudul "paguneman aki jeng incuna" (obrolan ringan kakek dengan cucu)

5. Ritual doa Ngabungbang di Cucurah Cikahuripan

Doa yang dibacakan adalah solawat untuk mengirim doa kepada leluhur masyarakat Desa Batulawang yang sudah mendahului mereka kemudian diakhiri dengan membaca surat Al-Fatihah.Pembacaan doa dilakukan di mata air tepatnya di kaki Gunung Sangkur. Mata air ini merupakan pusat air bagi masyarakat Desa Batulawang. Dalam perjalanan dari halaman masjid Desa sampai ke mata air, masyarakat dilarang untuk berbicara, mereka hanya diperbolehkan untuk berdoa disetiap langkah kakinya.

6. Tarian buhun Ronggeng Gunung

Setelah berdoa di Cikahuripan, masyarakat menuju ke lapangan untuk berpesta dimeriahkan oleh tarian Ronggeng Gunung yang dibawakan oleh Nyai Raspi sampai larut malam. Demikianlah pelaksanaan Tradisi Ngabungbang berlangsung.

Makna-makna Simbol dalam Tradisi Ngabungbang

Tradisi Ngabungbang sarat dengan makna yang terdapat dalam simbol-simbol seperti tersebut di bawah ini:

a. Bulan Purnama sebagai Waktu Sakral

Tanggal 14 Maulud dipercaya sebagai waktu yang sakral bagi masyarakat Jawa dan Sunda. Karena pada malam tersebut dimaknai sebagai simbol suci. Begitu juga bagi umat Muslim sekarang ini, bahwa bulan Maulud merupakan hari kelahiran Nabi Muhammad SWT.

b. Cucurah Cikahuripan sebagai tempat Keramat

Cucurah Cikahuripan sebagai sumber mata air bagi masyarakat Desa Batulawang. Tempat ini diyakini mempunyai kekuatan gaib karena apabila datang masa kemarau cucurah cikahuripan ini airnya tidak pernah surut.

c. Damar Sewu

Makna dari damar sewu yaitu untuk terhindarnya dari rasa kecemburuan sosial, semua warga merasakan satu perasaan yang sama tanpa ada jarak satu dengan yang lainnya. Selain itu juga supaya lebih memaknai dan menghargai para leluhur kita yang hidup dengan serba kekurangan tetapi tetap semangat dalam berjuang.

d. Beleketepe 
Makna beleketepe yaitu warga diajak belajar duduk sejajar diatas tikar yang terbuat dari daun kelapa. Filosofinya adalah bahwa dimata Allah SAW dan benteng pemisah diantara manusia itu lenyap seketika ketika masyarakat duduk bersila di atas beleketepe.

\section{e. Sajen}

Fungsi sajen secara umum yaitu alat persembahan pada yang gaib. Tetapi ada makna lain, dibalik sesaji yaitu supaya kita mengingat para leluhur sebagai keturunannya. Pada sesaji tersebut ada beberapa benda kesukaan leluhur diantaranya ada rokok yang terbuat dari daun jagung, rokok bangjo, rokok surutu, dan rokok-rokok tersebut merupakan kesukaan para leluhur warga desa Batulawang. Dalam sesaji juga ada bubur merah dan bubur putih ini merupakan simbol dari bendera Indonesia. Dan membuktikan bahwa para leluhur kita sudah memiliki rasa cinta tanah air. Selanjutnya yaitu sesaji nasi kuning, ini melambangkan perjalanan Nabi Muhammad SAW dalam membawa ajaran agama Islam. Selain sesaji nasi kuning, juga terdapat sesaji rempah dan sesaji lainnya yang kesemuanya itu merupakan hasil bumi Desa Batulawang.

Makna dari sesaji diatas adalah bahwa anak cucu mereka masih mengingat dan mendoakan para leluhurnya yang sudah mendahului mereka dengan menyertakan bendabenda kesukaan para leluhur
itu(Agus Safyudin, wawancara tanggal 28 Oktober 2016).

f. Rudat Solawat (Solawat yang menggunakan irama Sunda) Dan Reog Bedug

Kesenian ini merupakan karya anak bangsa yang sudah lama dilestarikan. Kesenian ini ada dimaksudkan untuk mendidik para generasi muda dalam menghormati tamu yang datang ke Desa Batulawang.

g. Silengser

Dalam sejarahnya silengser merupakan utusan raja yang tugasnya menyampaikan perintah raja pada rakyat, tetapi dengan diselingi humoran. Maknanya yaitu bahwa masyarakat desa Batulawang sangat menghormati tamu yang datang ke desanya (Agus Safyudin, wawancara tanggal 28 Oktober 2016).

h. Gondang Buhun

Gondang buhun merupakan kesenian yang alat musiknya terbuat dari lisung (kayu menyerupai perahu untuk menumbuk padi menjadi beras) dan halu (kayu panjang). Gondang buhun ini dimainkan oleh para ibu yang berjumlah duabelas orang dan ibu tersebut sambil menyanyikan lagu sebagai rasa syukur atas panen yang melimpah.

\section{i. Ronggeng Gunung}

Kesenian ronggeng gunung merupakan kesenian asli rakyat Jawa barat. Tarian ini dibawakan oleh beberapa penari wanita yang mengililingi dammar dan gerakannya berirama. Alat- 
alat musiknya diantaranya yaitu satu kendang, tiga buah bonang (ketuk, kempul, kenong) dan satu buah goong tanpa kempul. Lagu-lagu yang dinyanyikan yaitu trendol, raja pulang, sasanggaran yang menceritakan tentang pertarungan para bajo atau perompak.

2. Pewarisan Nilai Sejarah Tradisi Ngabungbang dalam Pembelajaran Sejarah Lokal dengan Metode Ekskursi Pada Mahasiswa Program Studi Pendidikan Sejarah FKIP Universitas Galuh

Pendidikan, yang berorientasi pada pengetahuan yang ditanamkannya, kapasitas berpikir yang dikembangkannya, dan berbagai kegiatan praktis yang dijalankannya, dapat menjadi instrumen yang potensial untuk membentuk kepribadian masyarakat melalui kesadaran sejarah yang ditanamkan di lingkungan sekitarnya. Sejarah selain memberi pengetahuan faktual juga membangkitkan perasaan sejarah (historical sense). Seiring dengan kemajuan ilmu pengetahuan dan teknologi serta perubahan zaman, yang berdampak pada kehidupan manusia, maka perlu dilakukan terobosanterobosan baru di dalam mengatasi permasalahan pendidikan.

Pembelajaran sejarah merupakan sebuah sistem yang mengintegrasikan berbagai komponen pembelajaran untuk mencapai tujuan pembelajaran yang diinginkan. Pemilihan komponen-komponen dalam pembelajaran harus dipikirkan dengan baik agar pembelajaran dapat berlangsung dengan efektif dan efisien. Komponen-komponen pembelajaran harus saling mendukung dan melengkapi untuk menghasilkan suatu proses pembelajaran yang bermakna dan mudah dipahami oleh siswa.

Peningkatan kualitas pendidikan merupakan suatu proses yang dilaksanakan secara dinamis dan berkesinambungan dalam upaya pencapaian tujuan pendidikan secara efektif dan efisien. Tujuan itu diwujudkan dalam bentuk kompetensi yang utuh pada diri peserta didik, tidak hanya kompetensi akademik, tetapi juga kompetensi sosial, dan kepribadian serta religius (Aman, 2011:3).

Pembelajaran sejarah lokal Tradisi Ngabungbang dengan menggunakan metode ekskursi merupakan hal yang sangat menarik mahasiswa, karena mahasiswa dapat menyaksikan langsung sebuah tradisi yang masih berkembang di masyarakat. Tradisi Ngabungbang ini dibahas dalam materi tentang "Tipe-Tipe Sejarah Lokal Tradisional" dalam mata kuliah Sejarah Lokal, yang diampu oleh ibu Dewi Ratih, S.Pd., M.Pd dimana dalam penelitian ini dijadikan sebagai dosen mitra. Metode ekskursi atau karya wisata ini sebelumnya sudah sering didengar oleh dosen mitra, namun beliau jarang melaksanakan pembelajaran dengan metode ekskursi tersebut karena terkendala waktu dan biaya.

Sebelum melakukan kunjungan ke lokasi, peneliti melakukan pengamatan di kelas terlebih dahulu. Peneliti melakukan pengamatan terhadap persiapan mengajar dosen dengan pembahasan tipe-tipe sejarah lokal tradisional yang berkaitan dengan tradisi Ngabungbang sebagai sumber belajar dengan metode ceramah. Pada penelitian pertama yang dilakukan di kelas, peneliti mengamati dari proses pembelajaran tersebut, dosen pengampu sudah melakukan upaya- 
upaya untuk mengembangkan pewarisan nilai-nilai sejarah melalui tradisi Ngabungbang.

Banyak mahasiswa yang tidak tahu dengan tradisi Ngabungbang ini. Dosen menjelaskan bahwa tradisi Nagbungbang ini merupakan acara melekan yang dilakukan masyarakat Desa Batulawang di Kota Banjar yang diadakan setiap satu tahun sekali. Dosen pengampu mata kuliah Sejarah Lokal menjelaskan prosesi tradisi Ngabungbang ini dimulai dari pra pelaksanaan sampai pelaksanaan.

Banyak mahasiswa yang penasaran dengan tradisi ini setelah mendengar penjelasan dari dosen. Dan tidak sedikit mahasiswa yang bertanya tentang waktu pelaksanaan tradisi Ngabungbang. Kemudian dosen menawarkan kepada mahasiswa untuk berkunjung langsung ke lokasi pelaksanaan tradisi Ngabungbang ini dan 99\% mahasiswa menyetujuinya. Tidak memakan waktu lama kemudian dosen dibantu ketua kelas untuk mempersiapkan kelompok. Kelas dibagi menjadi lima kelompok. Setelah pembagian kelompok mahasiswa diberikan arahan terlebih dahulu dari dosen mengenai tugas yang harus dilakukan oleh mahasiswa.

Pengamatan selanjutnya adalah di lapangan,mahasiswa dan peneliti serta dosen pengampu berangkat dari kampus pukul 16.00 WIB dengan menggunakan bis kampus dan sampai di lokasi pukul 18.00 WIB. Setelah sampainya di lokasi, kelompok mahasiswa yang telah ditugaskan segera melakukan tugasnya. Masingmasing kelompok diberi tugas yang berbeda-beda. Untuk kelompok pertama diberi tugas tentang pra pelaksanaan tradisi Ngabungbang, kelompok dua diberi tugas tentang pelaksanaan tradisi Ngabungbang, kelompok ketiga diberi tugas makna dari simbol-simbol dalam tradisi Ngabungbang, kelompok empat diberi tugas kesenian yang ada dalam tradisi Ngabungbang, dan kelompok terakhir diberi tugas mengenai nilai-nilai yang terkandung dalam tradisi Ngabungbang.

Masing-masing ketua kelompok membagi tugas pada anggotanya. Ada yang bertugas mewawancarai, baik itu mewawancarai tokoh adat dan agama, ada yang mewawancarai masyarakat, ada yang mewawancarai panitia penyeleggara dan ada yang mewawancarai dari unsur pemerintahan Kota. Ada mahasiswa yang bertugas mencatat hasil wawancara dan mendokumentasikan acara tradisi Ngabungbang. Mahasiswa antusias melaksanakan tugas yang mereka emban seolah-olah mereka tidak dalam proses pembelajaran dan mereka berbaur dengan masyarakat Desa Batulawang untuk sama-sama mengikuti prosesi tradisi Ngabungbang ini. Mulai dari pembukaan yaitu mendoakan arwah leluhur (senja unjukan), penyambutan tamu agung (Wali Kota), pementasan kesenian buhun seperti (gondang buhun, pencak silat, dogdog), pembacaan sejarah Desa Batulawang, doa di cucurah cikahuripan, dan pementasan Ronggeng Gunung.

Pengamatan ketiga yang dilakukan peneliti adalah presentasi/penyajian tugas oleh kelompok mahasiswa. Dalam perkuliahan kali ini dosen pengampu menggunakan metode diskusi. Materi yang didiskusikan adalah hasil observasi dari Tradisi Ngabungbang dan nilai-nilai yang terkandung didalamnya. Mahasiswa dituntut untuk melaporkan hasil penemuannya selama mereka melaksanakan observasi. Tata cara 
presentasinya yaitu masing-masing ketua kelompok maju ke depan untuk memaparkan hasil temuannya dan anggota yang lain duduk. Hal ini dilakukan untuk mengefektifkan waktu.

Kelompok pertama yang diketuai oleh Redi mempresentasikan laporannya dengan tema pra pelaksanaan Tradisi Ngabungbang yaitu sebagai berikut: "Dalam setiap pelaksanaansuatu acara maka terlebih dahuluada persiapan-persiapan yan harus dilakukan termasuk dalam TradisiNgabungbang. Persiapan untuk mensukseskan acara ini diantanya adalah yan pertama pembuatan dammar sewu, beleketepe sekaligus kolontang, panggung, dan sesaji. Semua masyarakat bergotong royong dalam persiapan acara tradisi Ngabungbang. Apabila ada yang berhalangan hadir, maka mereka menyumbangkan konsumsi untuk para warga lain yang bekerja. Dalam mempersiapkan dammar sewu ini, warga terutama laki-laki berbondongbondong mendaki kaki Gunung Sangkur untuk mengambil bambu dan kemudian dipotong-potong menjadi beberapa bagian. Setelah dipotong menjadi beberapa bagian, lalu bambu tersebut di susun dan dikasih sumbu kompor. Selain pembuatan dammar sewu, warga yang lain bergotong royong membuat beleketepe dan kolontang. Bahan beleketepe yaitu terbuat dari daun kelapa yang disusun dengan cara dianyam. Sehingga nantinya beleketepe tersebut dijadikan tempat untuk duduk bagi masyarakat. Selain pembuatan belekete juga terdapat warga lain yang membuat kolontang. Bahan kolontang sama terbuat dari daun kelapa dan pembuatannya juga dianyam menyerupai mangkuk. Gunanya yaitu untuk tempat makanan umbi-umbian. Seperti singkong, ubbi jalar, kacang tanah, terigu dan sebaginya. Selanjutnya yaitu pembuatan sesaji. Sesaji dibagi menjadi dua. Ada sesaji nasi tumpeng kuning dan ada juga sesaji rempah-rempah.

Ketua kelompok dari kelompok duayaitu Fikri mempresentasikan hasil temuannya. Yaitu mengenai pelaksanaan Tradisi Ngabungbang. Pelaksanaan tradisi Ngabungbang ini diawali dengan penyalaan damar sewu dan dilanjutkan dengan seja unjukan. Seja unjukan ini merupakan ritual mengirim doa untuk para leluhur yang sudah mendahului dan tidak lupa mereka minta izin pada sang khalik. Setelah itu penyambutan tamu yaitu wali kota banjar sebagai tamu agung. Dilanjutkan dengan pementasan kesenian buhun diantaranya adalah kesenian gondang buhun, kesenian calung dan angklung beserta dogdognya, kesenian pencak silat dan pementasan puisi musikalitas Sunda. Setelah itu dilanjutkan dengan pembacaan sejarah desa Batulawang dari tahun 1901-2016. Lalu pelaksanaan doa di mata air cikahuripan dan diakhiri dengan pementasan ronggeng gunung sebagai hiburan rakyat.

Presentasi selanjutnya dari ketua kelompok tiga yaitu Risna. Dia memaparkan hasil temuannya mengenai makna dari simbol-simbol dalam tradisi Ngabungbang. Bahwasannya Bulan Purnama Tanggal 14 Maulud dipercayaisebagai waktu sakral yaitu merupakan hari kelahiran Nabi Muhammad SWT. Selanjutnya adalah Cucurah Cikahuripan sebagai tempat keramat karena airnya tidak pernah surut sekalipun sedang keramarau panjang. Damar Sewu makna dari damar sewu yaitu untuk 
terhindarnya dari rasa kecemburuan sosial, semua warga merasakan satu perasaan yang sama tanpa ada jarak satu dengan yang lainnya. Selanjutnya makna beleketepe yaitu warga diajak belajar duduk sejajar diatas tikar yang terbuat dari daun kelapa. Filosofinya adalah bahwa dimata Allah SAW dan benteng pemisah diantara manusia itu lenyap seketika ketika masyarakat duduk bersila di atas beleketepe. Selanjutnya yaitu Sajen. Adamakna lain dibalik sesaji yaitu supaya kita mengingat para leluhur sebagai keturunannya. Dalam sesaji juga ada bubur merah dan bubur putih ini merupakan simbol dari bendera Indonesia. Dan membuktikan bahwa para leluhur kita sudah memiliki rasa cinta tanah air. Selanjutnya yaitu sesaji nasi kuning, ini melambangkan perjalanan Nabi Muhammad SAW dalam membawa ajaran agama Islam. Selain sesaji nasi kuning, juga terdapat sesaji rempah dan sesaji lainnya yang kesemuanya itu merupakan hasil bumi Desa Batulawang. Makna dari sesaji diatas adalah bahwa anak cucu mereka masih mengingat dan mendoakan para leluhurnya yang sudah mendahului mereka dengan menyertakan bendabenda kesukaan para leluhur itu.

Kelompok empat presentasi mengenai kesenian yang terdapat dalam tradisi Ngabungbang diantaranya Rudat Solawat dan Reog Bedug kesenian ini merupakan karya anak bangsa yang sudah lama dilestarikan. Kesenian ini ada dimaksudkan untuk mendidik para generasi muda dalam menghormati tamu yang datang ke Desa Batulawang. Silengser dalam sejarahnya silengser merupakan utusan raja yang tugasnya menyampaikan perintah raja pada rakyat, tetapi dengan diselingi humor. Maknanya yaitu bahwa masyarakat desa Batulawang sangat menghormati tamu yang datang ke desanya (Agus Safyudin, wawancara tanggal 28 Oktober 2016). Gondang buhun merupakan kesenian asli masyarakat Sunda.Alat musiknya terbuat dari lisung (kayu menyerupai perahu untuk menumbuk padi menjadi beras) dan halu (kayu panjang). Gondang buhun ini dimainkan oleh para ibu yang berjumlah duabelas orang dan ibu tersebut sambil menyanyikan lagu sebagai rasa syukur atas panen yang melimpah. Kesenian Ronggeng Gunung merupakan kesenian asli rakyat Jawa Barat. Tarian ini dibawakan oleh beberapa penari wanita yang mengililingi dammar dan gerakannya berirama. Alat-alat musiknya diantaranya yaitu satu kendang, tiga buah bonang (ketuk, kempul, kenong) dan satu buah goong tanpa kempul. Lagu-lagu yang dinyanyikan yaitu trendol, raja pulang, sasanggaran yang menceritakan tentang pertarungan para bajo atau perompak.

Kelompok lima mempresentasikan mengenai nilai-nilai yang terkandung dalam Tradisi Ngabungbang diantaranya; nilai religius, pedagogis, jujur, toleransi antar umat beragama, nilai estetis, nilai simbolis, disiplin, kerja keras, nilai sosial/sosialisasi, nilai ekonomis, kreatif, gotong royong atau dalam istilah sunda adalah liliuran, demokratis, rasa ingin tahu, melestarikan alam lingkungan, melestarikan kesenian, semangat kebangsaan, cinta tanah air, menghormati leluhur, kerukunan antar tetangga, bersahabat, cinta damai, tanggung jawab, etika kesopanan dalam istilah tata karma, tata sosial, etika dan sopan santun, norma.

Dibawah ini merupakan nilai-nilai yang terkandung di dalam Tradisi 
Ngabungbang diantaranya adalah sebagai berikut:

1. Nilai religius:

Yang ditanamkan dalam tradisi Ngabungbang pada masyarakat Desa Batulawang yaitu ketika akan memulai upacara ritual, terlebih dahulu dibuka dengan pembacaan ayat suci al-quran dan dilanjutkan dengan tawasulan. Tempat pelaksanaan berada tepat didepan madrasah. Selain untuk tempat menimba ilmu agama, madrasah juga sebagai tempat bermusyawarah warga Desa Batulawang dan sebagai sarana yang lainnya, termasuk sebagai sarana diadakannya upacara Tradisi Ngabungbang.

2. Pedagogis:

Sebagai usaha pendekatan dan proses pembelajaran untuk membentuk pegetahuan, sikap, watak dan keterampilan manusia. Yang hendak ditanamkan pada generasi muda yaitu nilai historis/sejarah untuk melestarikan tradisi yang diwariskan secara turun temurun dari nenek moyang agar tidak punah dan tetap terjaga.

3. Jujur:

Perilaku yang di dasarkan pada upaya menjadikan dirinya supaya dapat dipercaya. Dalam kegiatan tradisi Ngabungbang atau yang lainnya yang harus di utamakan adalah sikap kejujuran, seperti dalam kegiatan gotong royong bersama warga harus jujur dan tidak boleh ada pamrih.

4. Toleransi antar umat beragama:

Sikap dan tindakan yang menghargai perbedaan agama, karena di dalam pelaksanaan tradisi Ngabungbang semua orang yang berbeda agama berbaur menjadi satu untuk saling membantu.

5. Nilai estetis:

Keindahan dalam tradisi Ngabungbang diantaranya terdapat berbagai macam kesenian tradisional seperti gondang buhun (kesenian ini merupakan gambaran kehidupan zaman tradisional dimana para perempuan menumbuk gabah hasil panen untuk dikonsumsi besama keluarga).

6. Nilai simbolis:

Terdapat berbagai macam simbol-simbol yang pada intinya ditunjukan untuk kehadirat Allan SWT. Seperti terdapatnya janur kuning merupakan simbol dari kesucian.

7. Disiplin:

Dalam radisi Ngabungbang di ajarkan sikap disiplin, contohnya dalam berpakaian, dalam mengefektifkan waktu dan ketertiban dalam menyaksikan kesenian tradisional.

8. Kerja keras:

Sebelum dan sesudah acara terlebih dahulu mempersiapkan materill yang akan digunakan dalam upacara tradisional Ngabungbang, diantaranya warga secara bersamasama bekerja membuat damar sewu dan tanpa bayaran apapun.

9. Nilai sosial/sosialisasi

Upacara tradisi Ngabungbang dapat meningkatkan kegiatan sosialisasi antar masyarakat yaitu salah satunya adalah bersedekah atau memberi makanan berupa umbiumbian dalam pelaksanaan tradisi Ngabungbang.

10. Nilai ekonomis

Tradisi Ngabungbang dapat dijadikan sebagai event promosi pariwisata ritual kota Banjar.

11. Kreatif:

Tokoh adat Desa Batulawang yaitu Ki Demang Wangsafyudin S.H dapat membungkus suatu tradisi lokal yang kolot atau ortodok sehingga dapat diterima oleh masyarakat Desa Batulawang Khususnya oleh 
masyarakat Kota Banjar sehingga menjadi agenda tahunan kota.

12. Nilai Gotong royong atau dalam istilah sunda adalah liliuran.

Merupakan salah satu spirit pertama yang terkandung dalam kegiatan tradisi Ngabungbang.

13. Demokratis:

Dalam upacara ini tidak ada paksaan atau pengekangan bagi masyarakat setempat, bahkan pemerintahan membebaskan asalkan hal tersebut tidak keluar dari normanorma agama.

14. Rasa ingin tahu:

Setiap orang yang baru mendengar tradisi Ngabungbang ini penasaran dan merasa ingin tahu yang akhirnya mereka mengikuti upacar ritual ini.

15. Melestarikan alam lingkungan:

Diantaranya; membersihkan sumber mata air, tidak menebang pohon sembarangan, membersihkan lingkungan, menanam pohon di sekitar mata air supaya air selalu ada dan terpelihara. Meskipun saat kemarau, tetapi kesediaan air masih tetap ada dan masyarakat setempat tidak perlu khawatir karena air sudah disediakan oleh alam.

16. Melestarikan kesenian

Kesenian yang ditampilkan dalam tradisi Ngabungbang diantaranya; Ronggeng gunung, Gondang Buhun, Pencak silat, Permainan anak tradisional, Kecapi, Suling, Angklung, Kendang, Saron, Halu dan lisung, Beluk.

17. Semangat kebangsaan:

Acara ritual ini menempatkan kepentingan bangsa dan negara di atas kepentingan kelompok atau pribadi.

18. Cinta tanah air:

Tradisi Ngabungbang ini merupakan wujud dari kebudayaan nasional yang menumbuhkan rasa cinta tanah air.

19. Menghormati leluhur:

Patuh terhadap hal-hal yang ditabukan terhadap leluhur, nenek moyang dan menjaga kelestarian yang telah diwariskan nenek moyang terhadap mereka supaya generasi yang akan datang masih tetap dapat menyaksikan dan menjalankan tradisi tersebut.

20. Kerukunan antar tetangga:

Untuk saling menghormati antar tetangga, menjaga keharmonisan antar tetangga dan lebih mempererat tali silaturahim.

21. Bersahabat:

Tindakan senang bergaul dan bekerjasama sangat sesuai di dalam tradisi Ngabungbang. Karena tanpa berkomunikasi, mustahil acara ini akan terselenggara.

22. Cinta damai:

Setiap orang yang melaksanakan tradisi Ngabungbang ini akan merasa damai, karena ritual ini salah sattu pendekatan terhadap Tuhan Yang Maha Esa dan pendekatan diri terhadap alam ciptaan Tuhan.

23. Tanggung jawab:

Semua tindakan manusia harus ada tanggung jawabnya. Dalam tradisi Ngabungbang ini merupakan wujud tangggung jawab manusia terhadap alam kepada Tuhan yang menciptakannya. Agar manusia tidak merusak alam.

24. Etika kesopanan dalam istilah tata karma, tata sosial, etika dan sopan santun:

a) Mengucapkan sampurasun dan menjawab rampes ketika datang.

b) Membungkukan badan apabila berjalan dan melewati orang dan dengan mengucapkan kalimat punten atau permisi. 
c) Berpakain yang menutup aurat seperti pada laki-laki menggunakan pangsi dan perempuan menggunakan kebaya.

d) Berkata-kata yang sopan dan halus seperti mulih timana?, Wangsul tiditu, Geura neda, awis tepang, dan sebagainya.

\section{Norma}

Norma berarti aturan, ukuran, patokan kaidah bagi pertimbangan dan penilaian atas perilaku manusia (Sutarjo Adisusilo: 2013: 53).

26. Silih asah, silih asih, silih asuh:

Merupakan suatu proses yang menunjukan kausalitas. Untuk memberikan pengayoman atau saling mengingatkan dan harus didahului dengan pengenalan, kemudain saling mengingatkan. Artinya untuk mempertajam pengalaman tertentu, sebagai bagian dari instropeksi (Prof.Dr. H. Sobana, wawancara tanggal 28 Oktober 2016).

27. Pamali/tabu:

Maksudanya supaya generasi muda tidak sembarangan dalam bertindak dan harus mengenal pantangan. Yang disebut juga dengan larangan atau istilah bahasa Sunda panca gati (5 keadaan asali), yaitu (1). Jangan menipu, (2). Jangan ikut-ikutan (mudah ketularan sifat buruk), (3). Jangan memasuki rumah orang tanpa izin, (4). Jangan menetap di majikan, (5). Jangan meninggalkan tutur kata yang baik. Atja \& Saleh Danasasmita 1981 (dalam Edi S. Ekadjati, 2009: 183).

28. Cageur (sehat), bageur (sopan santun), beuneur (kebaikan), pinter (pintar), singer (kecekatan, sigap):

Maksudnya adalah supaya umat manusia memiliki jiwa yang sehat dan kuat baik jasmani dan rohaninya, teguh pendirian, empati dan memiliki kelakuan yang sopan dan santun baik terhadap yang usianya lebih tua maupun lebih muda, memiliki kepintaran secara pemikiran yang berasal dari hati dan tidak dapat merugikan orang lain bahkan sebaiknya, dan singer adalah memiliki sikap cekatan dalam pekerjaan dan sebagainya.

29. Melestarikan pakaian tradisional:

a) Kabaya; pakaian khas perempuan orang Sunda (mencerminkan keanggunan seorang perempuan, baik itu terletak pada pakaiannya maupun cara dia berjalan dan berbicara).

b) Pangsi; pakaian hitam untuk laki (mencerminkan kesederhanaan).

c) Iket; penutup kepala untuk lakilaki (mencerminkan bahwa kepala manusia sudah difitrahi, jadi harus dijaga kesuciannya).

d) Kain samping untuk perempuan (mencerminkan jati diri bangsa)
e) Gelung atau konde (mencerminkan keanggunan perempuan).

30. Melestarikan makanan dan minuman tradisional:

a) Beubeutian (umbi-umbian); talas, singkong, terigu, ubi, kacang tanah dan sebagainya yang direbus terlebih dahulu.

b) Bajigur minuman jahe yang dapat menghangatkan tubuh.

Salah satu cara untuk mengenal jati diri seseorang atau suatu bangsa, dapat diketahui melalui perilakunya dalam berinteraksi dengan Sang Maha Pencipta, umpama dalam acara ritual keagamaan, dengan manusia lain dalam berinteraksi sosialnya dan dengan lingkungannya (yaitu tentang bagaimana seseorang atau suatu 
kelompok masyarakat memperlakukan lingkungannya). Dari kacamata kebudayaan, perilaku anggota masyarakat yang dapat diobservasi itu dimotori oleh ide atau pikiran yang besemi dalam diri manusia atau suatu kelompok masyarakat (Mashadi, dkk, 2010: 21).

Dan pada intinya nilai-nilai dari tradisi Ngabungbang adalah mewujudkan manusia supaya tahu pada jati dirinya. Apabila sudah tahu pada jati dirinya maka akan tahu pada budayanya dan apabila manusia itu sudah tahu akan budayanya maka akan tahu pada jati dirinya, dan apabila sudah tahu pada jati dirinya maka manusia tidak akan merusak alam sekitarnya.

Nilai-nilai tradisi Ngabungbang relevansinya terhadap nilai-nilai budaya lokal sangat erat sekali hubungannya, karena di dalam pelaksanaan Ngabungbang terdapat banyak nilai budaya lokal yang di junjung tinggi oleh masyarakat setempat. Hal ini sangat positif apabila nilai-nilai yang terdapat di dalam tradisi Ngabungbang di relevansikan terhadap pembelajaran sejarah di sekolah. Karena di dalam nilai-nilai tradisi Ngabungbang terdapat nilai karakter dan budaya bangsa.

Unsur budaya yang dikenal masyarakat secara universal terdiri atas tujuh unsur, yakni; sistem religi atau keagamaan, sistem teknologi dan benda materil, sistem mata pencaharian hidup atau ekonomi, sistem kemasyarakatan atau organisasi sosial, sistem ilmu pengetahuan atau pendidikan, sistem bahasa, dan seni (Koentjaraningrat, dalan Elis Suryani, 2010: 52). Diantara unsur budaya diatas, dalam tradisi Ngabungbang terdapat beberapa unsur, diantaranya adalah keagamaan, kesenian tradisional, bahasa, sopan santun atau etika, menjaga lingkungan, sistem teknologi, pakaian tradisional, makanan dan minuman tradisional dan lain sebagainya.

\section{Simpulan Dan Saran}

Simpulan

Prosesi pelaksanaan Tradisi Ngabungbang terdiri dari dua tahap, yaitu tahap pra pelaksanaan dan tahap pelaksanaan. Sebelum pelaksanaan, dibuatlah damar sewu, beleketepe, dan sajen. Pelaksanaan Tradisi Ngabungbang ini diawali dengan penyalaan damar sewu dan dilanjutkan dengan seja unjukan. Seja unjukan ini merupakan ritual mengirim doa untuk para leluhur yang sudah mendahului dan tidak lupa mereka minta izin pada sang khalik. Setelah itu penyambutan tamu yaitu wali kota banjar sebagai tamu agung. Dilanjutkan dengan pementasan kesenian buhun diantaranya adalah kesenian gondang buhun, kesenian calung dan angklung beserta dog-dognya, kesenian pencak silat dan pementasan puisi musikalitas Sunda. Setelah itu dilanjutkan dengan pembacaan sejarah Desa Batulawang dari tahun 1901-2016. Lalu pelaksanaan doa di mata air cikahuripan dan diakhiri dengan pementasan Ronggeng Gunung sebagai hiburan rakyat.

Nilai-nilai yang terkandung dalam Tradisi Ngabungbang diantaranya; nilai religius, pedagogis, jujur, toleransi antar umat beragama, nilai estetis, nilai simbolis, disiplin, kerja keras, nilai sosial/sosialisasi, nilai ekonomis, kreatif, gotong royong atau dalam istilah sunda adalah liliuran, demokratis, rasa ingin tahu, melestarikan alam lingkungan, melestarikan kesenian, semangat kebangsaan, cinta tanah air, menghormati leluhur, kerukunan antar 
tetangga, bersahabat, cinta damai, tanggung jawab, etika kesopanan dalam istilah tata karma, tata sosial, etika dan sopan santun, serta norma. Pewarisan nilai Tradisi Ngabungbang dalam pembelajaran sejarah pada mahasiswa Program Studi Pendidikan Sejarah cukup optimal dengan digunakannya pembelajaran kontekstual oleh dosen Mata Kuliah Sejarah Lokal melalui metode ekskursi atau metode karya wisata ke tempat diadakannya Tradisi Ngabungbang, yaitu di Desa Batulawang Kecamatan Pataruman Kota Banjar. Hal ini ditandai dengan baiknya tingkat pemahaman mahasiswa terhadap nilainilai Tradisi Ngabungbang.

Saran

1. Bagi Pemerintah, perlu adanya inventarisasi tradisi yang masih ada dan kajian nilai-nilai yang terkandung sebagai bahan bacaan bagi peserta didik dan bahan ajar bagi tenaga pendidik.

2. Bagi perguruan tinggi dan sekolah, perlu melibatkan peserta didik dalam pelaksanaan agar menumbuhkan rasa cinta tanah air, rasa memiliki, dan sebagainya. Perlu juga adanya pembahasan bersama sehingga akan muncul persamaan persepsi tentang nilai-nilai yang terkandung dalam tradisi yang ada di masyarakat.

3. Bagi masyarakat, diharapkan adanya kepedulian terhadap upacara tradisi dengan ikut andil dalam kegiatan tersebut.

\section{DAFTAR PUSTAKA}

Adisusilo,Sutarjo. 2013. Pembelajaran Nilai Karakter Konstruksi dan VCT sebagai Inovasi Pendekatan Pembelajaran Afektif. Jakarta: Raja Grafindo Persada.
Aman. 2011. Model Evaluasi Pembelajaran Sejarah. Yogyakarta: Ombak.

Bishop, Penny A dan Kathleen Brinegar.Winter 2011. "Student Learning And Engagement In The Context Of Curriculum Integration". Middle Grades Research Journal. 6.4. p207. (http://go.galegroup.com/ps/i.do?i $\mathrm{d}=$ GALE \% 7CA284016019\&v=2.1 $\& u=\mathrm{kpt} 04022 \& \mathrm{it}=\mathrm{r} \& \mathrm{p}=\mathrm{GPS} \& \mathrm{sw}=$ w\&asid=63537d77ee9ac4309719b 5bf7e2a1338)

Ekadjati, Edi S. 2009. Kebudayaan Orang Sunda: Zaman Pajajaran. Jakarta: Pustaka Jaya.

Fountain,Gregor ; Michael Harcourtdan Mark Sheehan. May 2011. "Historical Significance And Sites Of Memory". Set: Research Information for Teachers (Wellington). p26. (http://go.galegroup.com/ps/i.do?i $\mathrm{d}=\mathrm{GALE} \%$ 7CA272739076\&v=2.1 $\& \mathrm{u}=\mathrm{kpt} 04022 \& \mathrm{it}=\mathrm{r} \& \mathrm{p}=\mathrm{GPS} \& \mathrm{sw}=$ w\&asid $=5465$ b 1453 cddef $5 f 20 c 96$ $42060 \mathrm{e} 4575 \mathrm{c})$

Furchan, Arief. 2011. Pengantar Penelitian Dalam Pendidikan. Yogyakarta: Pustaka Pelajar.

Komalasari, Kokom. 2010.Pembelajaran Kontekstual. Bandung. PT. Refika Aditama. Moleong, Lexy. 2006. Metodologi Penelitian Kualitatif.Bandung :

Remaja Rosda

Karya.

Roestiyah. 2001. Strategi Belajar Mengajar. Jakarta: Rineka Cipta.

Rosidi, Ajib. 2011. Kearifan Lokal Dalam Perspektif Budaya Sunda. Bandung. Kiblat.

Sagala, Syaiful. 2006.Konsep dan Makna Pembelajaran: untuk Membantu Memecahkan Problematika Belajar dan 
Mengajar. Bandung: Alfabeta

Setiadi, Elly M. Hakam, H Kama A. Efendi, Ridwan. 2006. Ilmu Sosial dan Budaya Dasar.Jakarta. Kencana Prenada Media Group.

Sugiyono. 2013. Metode Penelitian Kuantitatif, Kualitatif, dan $R \& D$. Bandung: Alfabeta.
Suryani, Nunuk dan Leo Agung. 2012. Strategi Belajar Mengajar. Yogyakarta: Ombak. 